\title{
The application of GMOs in agriculture and in food production for a better nutrition: two different scientific points of view
}

\author{
M. Buiatti · P. Christou • G. Pastore
}

Received: 4 May 2012/Accepted: 3 August 2012/Published online: 18 October 2012

(c) The Author(s) 2012. This article is published with open access at Springerlink.com

\begin{abstract}
This commentary is a face-to-face debate between two almost opposite positions regarding the application of genetic engineering in agriculture and food production. Seven questions on the potential benefits of the application of genetic engineering in agriculture and on the potentially adverse impacts on the environment and human health were posed to two scientists: one who is sceptical about the use of GMOs in Agriculture, and one who views GMOs as an important tool for quantitatively and qualitatively improving food production.
\end{abstract}

Keywords Genetically modified food $\cdot$ Food production . Agro food science

Since the mid-1990s, the release of GMOs into the environment and the marketing of foods derived from GM crops has resulted in a scientific and public debate. Despite the potential benefits of the application of genetic engineering in agriculture in order to improve the quality and the reliability of the food supply, since the beginning, public and scientific concerns have been raised in many parts of the world about environmental and food safety of GM crops.

\footnotetext{
M. Buiatti ( $\square)$

University of Florence, Florence, Italy

e-mail: buiattister@gmail.com

P. Christou ( $\square)$

Universitat de Lleida - Agrotecnio Center and ICREA,

Barcelona, Spain

e-mail: christou@pvcf.udl.es

G. Pastore $(\bowtie)$

National Institute for Research on Food and Nutrition, Rome, Italy

e-mail: pastore@inran.it
}

Two major different points of view have been expressed by the community: on one hand, recombinant DNA technology is seen as a potent tool for enhancing crop productivity (first generation GMOs) and food quality (second generation GMOs) or "drug factories", for the production of vaccines and/or therapeutic medicines (third generation GMOs). GMO supporters point to evidence that GMOs must be considered essential for promoting sustainable agriculture, as they may be able to reduce agriculture's environmental footprint, reducing the use of pesticides, saving fossil fuels, decreasing $\mathrm{CO}_{2}$ emissions and conserving soil and moisture (James 2011). Supporters also consider GM crops indispensable in facing the severe global food and nutrition security problem in developing countries: although GM crops are not presented as the "absolute solution", it has been stated that they could undoubtedly make a significant contribution to an array of measurements and incentives to this constantly growing problem (Conner et al. 2003).

On the other hand, antagonists argued that the side effects in terms of potentially adverse impacts on the environment and human health are still largely unknown, and probably unknowable for decades, and encourage waiting for the final outcome of further research and utilization. Many concerns have been raised for the environment: the capability of a GMO to escape from confinement and therefore potentially to transfer engineered genes into wild populations, the persistence of the gene after a GMO has been harvested, the susceptibility of non-target organisms to the gene product, the instability of new genes, the reduction of the spectrum of other plants resulting in a significant loss of biodiversity and an increase in the use of chemicals in agriculture. As for human health, the main concerns have been the possibility of a transfer of allergens into the new foods, the gene transfer from GM foods to 
human cells or to bacteria in the gastrointestinal tract, which can cause worries especially transferred genetic material proved to adversely affect human health the transfer of genes from GM plants into conventional crops or related species in the wild, as well as the mixing of GM crops with those derived from conventional seeds, that could have an indirect effect on food safety and food security.

The same debate also occurs at the societal level. It is obvious that without "approval" by society at large, GM crops will surely fail in the marketplace. The forthcoming years, then, will be crucial for the commercial and economically viable application of GMOs in agriculture and food production (Nap et al. 2003). Consumer attitudes with respect to genetically modified foods differ widely, particularly between North America and Europe. Information asymmetry, incomplete information and uncertainty arise as a result of concerns over GMOs. The major concerns have arisen particularly in western Europe, where a general lack of awareness about how our food production system evolved, the strong opposition by activist groups and a steady stream of negative opinions in the media rapidly increased the resistance to GMO production and use among consumers. This point of view was rapidly endorsed by politicians. The European consumer confidence in the safety of food supplies had decreased significantly in the 1990 s as a result of a number of food "scandals" that, although not related to GM foods, left consumers to a state of uncertainty regarding the validity of risk assessments, both with regard to consumer health and environmental risks, focusing in particular on long-term effects.

With regard to foods derived from GM crops, consumers have not perceived any direct advantage, and therefore the public attention focused on the risk side of the risk-benefit equation.

As a consequence of the different American and European public attitudes towards this technology and the foods produced, the regulatory approaches in Europe and North America are essentially different: in the EU regulatory policy is based on the process of making GM crops; in the USA on the characteristic of the GM product.

In the EU, strong public concerns about GMOs triggered the imposition in October 1998 of a de facto moratorium on the authorization of new releases of GMOs in the European Union, and even stricter standards were proposed in the EU's revised Directive 90/220 of August 2000. Before the imposition of the moratorium, releases of GMOs were reviewed on a case-by-case basis and had to be approved at every step from laboratory testing through field testing to final marketing. By contrast, the permit procedure in the United States is far simpler and faster.

Consumer concerns have triggered a discussion on the desirability of labelling GM foods, allowing an informed choice. The different attitudes of the consumers in EU and
USA have led to marked differences in national labelling requirements. The US Food and Drug Administration does not require labelling of GM foods per se, but only if the transgenic food is substantially different from its conventional counterpart. The EU, by contrast, requires labelling of all foodstuffs, additives and flavours containing $1 \%$ or more genetically modified material (Regulations 1139/98 and 49/2000).

Within this picture, seven different questions were posed to two scientists representing the two different points of view: Prof. Marcello Buiatti (Dept of Genetics at the University of Florence, Italy), who is sceptical about the use of GMOs in agriculture, and Prof. Paul Christou (Dept. of Plant Production and Forestery Sciences, University of Lleida, Spain), who represents those who view GMOs as an important tool for quantitatively and qualitatively improving food production.

1. Concerns have been raised that GM crops will hybridize with related species resulting in the introgression of transgenes to weedy relatives. For transgenes conferring resistance to pests, diseases and herbicides, it has been suggested that this can also lead to an enhanced fitness, survival and spread of weeds. On the other hand, GM crops have been proposed as "friendly" bioherbicides and bioinsecticides, suggesting that future GMOs will be useful for soil, water, and energy conservation and for the natural waste management. Are GMOs, then, a risk or an opportunity to maintain the health of the environment?

\section{Buiatti:}

I do not really see at this moment any possible advantage from GMO cultivation for the health of the environment. I do not really remember reductions in tillage practices favorable to the environment, as the only reduced practice is man-made weed destruction, certainly advantageous for the owners of the fields because of the very low level of manpower needed in the case of herbicide resistant crops, but of irrelevant as far as environment management is concerned. Moreover, as the herbicide can in this case be utilized all along the cycle, many more treatments can be carried out and it is widely known that glyphosate exerts detrimental effects on the soil ecosystem and may be polluting ground water.

On the other hand, transgene flow to weedy relatives particularly of canola, an outbreeding species liable to hybridize to other Brassicaceae (Beckie et al. 2009), and of maize in the area of the origin of the species, has been shown to occur (see for instance Snow 2009). However, only the maize case is relevant for the ecosystem structure, as it may hybridize with the ancestor species teosinte, while the real danger of the hybridization of weed Brassica 
species is mainly relevant for agriculture as it may render them resistant to herbicides. The problem here is that gene flow evaluations are based on pollution probability studies, forgetting the fact that even low levels of pollen can flow to a few unintended GM plants can lead to each producing a large amount of pollen, putatively polluting neighbouring plants. Anyway the problem about pollution is not in my opinion health related but property related, as leading companies can sue any owner of a field having, without his will, even very few GM plants, according to the industrial patents covering all fields containing any amount of the patented objects.

Much more relevant are, in my opinion, the side-effects on ecosystems and particularly on the soil animal and microbial flora, both extremely relevant factors for the life of the highly inter-connected agro-ecosystem. On the contrary, as already discussed by Ch. Darwin in his treatise on worms, plants are connected through reciprocal exchange of nutritional components with the microbial flora and fauna, both liable to be affected by all agricultural practices from the use of chemicals, soil management, water distribution, etc. For this reason, the impact of GMOs will not only derive from the plant itself but also from its exudates and the agricultural practices to which single genetically modified plants (GMPs) are connected. In the case of GMPs resistant to herbicides, for instance, the effects of the herbicide itself (particularly glyphosate and the adjuvants present with it in commercial preparations) should be considered in all details in a holistic way, as summarized in an excellent review by Huber 2010, a very good example of risk evaluation through the integrated analysis of all the interactions with the plant itself, the nutrients in the soil and the soil microflora (on that subect, see also the review by Kremer and Means 2009). As far as the Bt GMPs are concerned, as thoroughly discussed in a recent review by Icoz and Stotzky 2008, Bt plants showed changes in the microbial communities' compositions, both as far as bacteria and fungi are concerned, and particularly mycorrhizae, a key group of fungi for plants nutrition (Castaldini et al. 2005; Giovannetti et al. 2005). All the examples just quoted are, however, only the direct effects on the agro-ecosystem of the transgenic plants themselves or of the agricultural practices associated to their cultivation but, as I will try to better discuss in my answer to a different question, the real damage to the ecosystem is not directly related to the genetic modification but derives from the economy, particularly of soybean cultivation in very large areas of developing countries and also of emerging ones, particularly in Latin America where large forested or traditionally cultivated areas have been converted to industrial soybean cultivation with a very relevant loss of the preexisting biodiversity.

I shall not comment on the possible future GMPs not on the market, as I am used, particularly in this area, not to try to predict the future behaviour of industry and the markets, the reason being discussed in my response to question 3 . In fact, the presently utilized technology of genetic engineering has not been improving for a long time; the research intensity of leading GM Companies has been constantly reduced. Particularly, no innovation has been introduced to avoid "unintended effects" of the interactions between the inserted sequences and the receiving organism, nor has any technique been developed allowing one to aim the construct in specific areas of the host genome to avoid the insertion and negative modification of relevant sequences of the original DNA. Certainly the lack of progress in those fields may seem amazing and can be justified only with the fact that the revenues of the leading companies do not come from innovation but from the royalties of already existing GMPs, advertising and stock exchange speculation.

\section{P. Christou:}

Gene flow does occur between GM crops and related weeds and wild species, but the consequences of this process are exaggerated. Taking herbicide tolerance first, it is important to recognize that although herbicide-tolerant transgenic plants have a selective advantage in cultivated areas where herbicides are applied, they have no such advantage elsewhere. Therefore the energetic burden of producing unnecessary detoxification enzymes and the genetic burden of possessing inefficient herbicide target enzymes can often make such plants less fit than their weedy and wild counterparts, naturally selecting against them in wild ecosystems where herbicides are not used, or in rotational agricultural ecosystems where the herbicide is rotated (Gressel 2002). Weedy species also tend to be more resistant to insects and diseases than domesticated crops because they produce toxins that fend off pests and pathogens. These toxins have been bred out of our crops because the toxins affect humans, too, which is one reason crops are more susceptible than weeds to insect pests (Gressel 2008). Therefore, additional resistance transgenes have little impact on the fitness of weeds and are soon diluted from the population (Gressel 2008). In cases where a real risk is envisaged, such as controlling weedy rice in monoculture rice paddies, there are adequate technologies to mitigate gene flow (Gressel 2012). Different species (transgenic or otherwise) will undergo different levels of gene flow, so the only rational way forward is to evaluate them on a case-by-case basis using science-based risk assessment procedures clearly divorced from any political interference. The risk assessment must be initiated by the applicants developing GM crops, and they must supply all necessary information to the regulatory agencies appointed to perform such evaluations professionally and impartially (EFSA 2010). Notwithstanding the above, the fear of gene flow damaging the environment has resulted in European 
legislation to mitigate gene flow using a plethora of barrier and distance-related measures (Ramessar et al. 2010; Morris and Spillane 2010). Molecular biologists have also been encouraged to develop strategies to prevent gene flow by developing systems for selectable marker excision (Hare and Chua 2002). Ironically, the focus on gene flow means that little is being done to prevent or control the introduction of exotic and potentially invasive species, which in principle could be far more damaging than new varieties (including GM varieties) of the domesticated plant species currently under cultivation. A 10-year study in the UK demonstrated that GM corn, potato, rapeseed and sugar beet lines are no more invasive or persistent than their conventional counterparts (Crawley et al. 2001).

GM crops are currently submitted for risk assessment on a case-by-case basis using science-based risk assessment procedures, and it is acknowledged that (as with all other technologies and, indeed, in all other areas of life) we cannot expect zero risk. Some modifications could be irreversible and the question is then whether it might be prudent to accept a "very low risk" of "irreversible hazardous modifications", or follow the "zero risk approach" as contemplated by a number of environmental organizations. It might therefore be instructive to address this theoretical scenario. The reversibility of the GM trait is influenced by the competitive advantage under natural conditions conferred by the introduced trait and the ability of the GM plant to transfer such traits to wild plants. Neither of these risk factors has been found in the GM crops cultivated in the EU or any of the crops that have received a positive EFSA Scientific Opinion. The target of "zero risk" to the environment as enshrined in the current EU legislation for GMOs would be sound if agriculture in its entirety were a "zero risk" activity for humans, but this is not the case. However, the approval delays in the EU do pose a definitive and quantifiable risk for the safety of humans and the environment as they contribute to the perpetuation of older and less safe technologies, such as the use of chemical pesticides.

The focus on risks also draws attention away from the clear environmental benefits of GM crops, including the fact that herbicide-tolerant crops allow the adoption of reduced tillage and conservation tillage practices, increasing carbon retention in the organic matter of the soil, restoring populations of organisms living or nesting in the soil, e.g. earthworms, ants and birds (Tebrügge 2010; Belmonte 1993), and reducing the use of fuel needed for tillage operations (Service 2007; Brookes and Barfoot 2009). Similarly, pest-resistant GM crops expressing Bt proteins are environmentally beneficial because there is no need to spray broad-spectrum pesticides onto the plants, thus reducing the use of fuel and avoiding environmental contamination with chemical pollutants (Smale et al. 2009), a strategy that also benefits non Bt-corn growers (Hutchinson et al. 2010). Bt toxins are highly specific and are confined within the plant so that only pests actually attacking plants are affected, not beneficial insects and microbes. Bt toxins are therefore recommended for more sustainable integrated pest control programs (Romeis et al. 2006; Sanahuja et al. 2011). It is again ironic that detractors focus on the theoretical risks of gene flow from pest-resistant crops (theoretical because Bt-crops have a $100 \%$ safety record in the 15 years since they were first planted commercially (Sanahuja et al. 2011)) while ignoring the much greater environmental burden of broad-spectrum insecticides that essentially wipe out the entire insect ecosystem in an agricultural setting and are well known to be toxic to humans (Sanahuja et al. 2011). The impressive safety record of Bt crops is unprecedented, yet $\mathrm{Bt}$ crops in Europe are subject to draconian rules which even the EC has admitted make no sense (Ramessar et al. 2008a, 2009; Sanahuja et al. 2011).

Soil animal and microbial flora are very important factors for the agro-ecosystem, so it is important to ask whether GM crops have a negative effect on soil organisms. All peer-reviewed studies published thus far clearly demonstrate that any effect of GM crops on soil microbial flora is lower in magnitude than effects related to location, seasonal variations and (most importantly) conventional/ organic agricultural practices such as tillage. EFSA concluded in its Opinion for continued cultivation of MON810 in the EU (The EFSA Journal 2009 1149, 1-85): "The EFSA GMO Panel is of the opinion that potential effects on soil microorganisms and microbial communities due to corn MON810 if they occur, will be transient, minor and localised in different field settings and are likely to be within the range currently caused by other agronomic and environmental factors." This conclusion on the safety of MON810 corn has been confirmed in recent papers on the impact of Bt corn on endophytic bacteria (Prischl et al. 2012). The impact of the herbicide glyphosate on NK603 corn mycorrhiza has also been found to be lower than conventional herbicides (Barriuso et al. 2010, 2011a), and does not change the corn rhizobacterial communities compared to those in untreated soil (Barriuso et al. 2011b).

2. The introduction of foreign genes into food plants has been considered to have an unexpected and negative impact on human health, in particular for the introduction of new allergens and/or for the effects of possible horizontal gene flow or any other unknown and uncontrollable effect of the transferred gene. On the other hand, future GM organisms are likely to include plants with increased nutrient levels, plants producing pharmaceutically important molecules and plants with improved resistance to diseases, cold, or drought, thus suitable for increasing food security in disadvantaged areas. Are GMOs, then, a risk or a potential benefit for human health? 


\section{P. Christou:}

GM food crops were first planted commercially in 1996 and in 2010 they were cultivated on 148 million ha of land (James 2010). In all that time there has been not one single report of an adverse event caused by the consumption of GM food products; no reports of toxicity or allergenicity. Indeed, no difference in nutritional or organoleptic properties compared to the non-GM equivalent [have been reported] at all. Several widely discussed reports about the potential adverse effects of GM crops in animal studies have also been comprehensively debunked (Sears et al. 2001; Shelton and Sears 2001; Ricroch et al. 2010; Batista and Oliveira 2009). StarLink is often put forward as an example of potential toxicity or allergenicity, but it is important to note that the summary of the investigation by the US Centers for Disease Control is very clear: "These findings do not provide any evidence that the reactions that the affected people experienced were associated with hypersensitivity to the Cry9c protein." The details can be found at http://www.cdc.gov/nceh/ehhe/Cry9Creport/.

More recently, microRNAs from plants were reported to accumulate in mammalian blood and tissues, where they "might be able to regulate gene expression" (http://thescientist.com/2011/09/20/plant-rnas-found-in-mammals/). The subtitle of this publication, "MicroRNAs from plants accumulate in mammalian blood and tissues", is grossly exaggerated. The biological activity was not seen in a normal diet, but after ingestion of a raw rice diet by rats equivalent to $33 \mathrm{~kg}$ of rice per day for a human. The report also neglects to mention that microRNAs are a natural form of gene regulation in all plants and animals, and that humans therefore consume millions of plant and animal miRNAs every day in normal diets without any known effect. Furthermore, the pharmaceutical industry has struggled for over a decade to develop oral medications based on RNA-mediated gene regulation without success, because it is extremely difficult to persuade the human body to absorb these molecules in a functional form because of the significant degradation that takes place in the gut. It is interesting that reaction to this report has immediately focused on the potential for negative effects while leaving out an important potential application of microRNAs: "Although the team has still a long way to go in elucidating the mechanisms by which plant microRNAs can regulate gene expression in humans, these initial results promise to increase the understanding of how specific ingredients in food can mediate health and disease". This was a statement by Clay Marsh, Director of the Center for Personalized Health Care at the Ohio State University College of Medicine, who studies microRNA expression in human blood but was not actually involved in the research discussed above.
Despite the extraordinary safety record of GM crops, GM agriculture as a whole faces the most restrictive regulatory framework outside the nuclear industry (Ramessar et al. 2008a, 2009, 2010). This dogmatic requirement for "zero risk" is astonishing when one considers that all other technologies and activities in the human sphere of existence, including nuclear energy, are considered as part of a risk/benefit trade-off. For example, all known drugs have adverse effects but are accepted because they have a beneficial role in treating disease, many (natural) foods have well-known adverse health effects yet people consume them anyway, and other allergenic plant-derived products are accepted without question-for example, approximately $5 \%$ of the world's population are allergic to natural rubber but there is no crusade to have this substance banned and the plantations destroyed (Sussman et al. 1991). The central issue with GM crops is that because there are no concrete adverse effects for people to quantify, they can only focus on theoretical and largely unquantifiable ones. The hysteria about horizontal gene transfer is a key example of this phenomenon (Twyman et al. 2009). It is well known that genes can be transferred horizontally between bacteria, and from bacteria to higher plants (one of the methods scientists use to transfer DNA to plants exploits bacteria). There is no evidence that antibiotic resistance transgenes have transferred horizontally from plants to bacteria that are human pathogens, therefore placing human health at risk, but no scientist can claim such an event is impossible, so there has to be a small but non-zero theoretical risk (in the same way that there is a small but non-zero theoretical risk that someone walking down the street may be struck by a piano falling from a cargo plane). However, on the basis of infinitesimal theoretical risk, the use of antibiotic resistance genes as markers in GM plants is now strongly discouraged (Ramessar et al. 2007). The great irony is that these antibiotic resistance genes are themselves entirely natural and are present in billions of bacteria all over the world. Every time someone eats non-GM fruits and vegetables, they are consuming these bacteria and the genes they contain. As stated above, gene transfer between bacteria is a wellknown and very common natural occurrence so, again theoretically, these natural bacteria would provide a much more likely source of antibiotic resistance to transfer to human pathogens in the gut, yet this process has never been documented (Ramessar et al. 2007). Finally, the selective antibiotics are no longer used in a clinical setting, so even if resistance did jump to human pathogens, it would have no impact at the point of care. Even so, millions of euros were invested into the development of politically expedient technologies to remove antibiotic resistance markers, thus ensuring the risk of transference from GM plants was 
reduced from almost zero to zero, when nature teems with the very same antibiotic resistance genes and no steps are taken to avoid them. There are no other technologies that demand zero risk, certainly none with such impressive credentials that the EU could state in a report following a 15-year study (1985-2000) involving 400 public research institutions and costing 70 million euros: “... genetically modified plants and products derived from them present no risk to human health or the environment......these crops and products are even safer than plants and products generated through conventional processes" (EC Research 2001; Kessler and Economidis 2001). In a subsequent report covering the next decade, the EU commission affirmed this outcome and reiterated: "The main conclusion to be drawn from the efforts of more than 130 research projects, covering a period of more than 25 years of research, and involving more than 500 independent research groups, is that biotechnology, and in particular GMOs, are not per se more risky than e.g. conventional plant breeding technologies" (European Commission 2010a).

As with the first question, the focus on imperceptible risks means that the many potential benefits of GM agriculture are ignored. It is generally acknowledged that first-generation GM crops provide higher yields with fewer inputs (principally fuel and pesticides), which has important economic benefits for the agricultural industry in the industrialized world, but the more significant positive effects are seen in the developing world where GM crops allow subsistence farmers not only to survive but to take surplus produce to market, providing additional wealth that supports education, improves access to medicines, and leads to the empowerment of women (Christou and Twyman 2004; Yuan et al. 2011). However, the hysterical anti-GM activism and the resulting political expediency is seriously delaying this process, particularly by holding back the deployment of newer firstgeneration GM crops that are protected from drought, salinity and better suited to grow in hostile environments, as well as second-generation GM crops that have enhanced output traits such as better nutritional composition (Farre et al. 2011b). The industrialized world has the luxury of choice, at least for the time being, but in the developing world GM crops could turn the tide against plant diseases and pests, eliminate damaging agricultural practices, reduce hunger and malnutrition and produce cheap medicines in response to some of the world's most pressing socioeconomic concerns (Farre et al. 2010; Gómez-Galera et al. 2010). It is no exaggeration to say that the anti-GM precedent currently set by Europe is indirectly contributing to death on a massive scale in Africa and Asia (Potrykus 2010).

\section{Buiatti:}

When I am asked this question I usually answer that I do not know for sure and the reason for this answer is that control agencies are not reliable. I do not frankly know exactly what happens in all countries, but I believe it to be similar to what we have here in Europe with EFSA, which I do know fairly well. The main problems with EFSA are two. In the first place, EFSA does not utilize independent laboratories for the control of GMO bio-safety, and therefore relies on the answers from the producer companies to the questions posed by specific scientific committees. Therefore, while those committees are, as far as we know, quite independent, of course companies certainly are not and, moreover, they keep sending back the conclusions of their laboratories and not the raw data. Therefore it is also impossible to check the reliability of the statistical treatment of the results, as happened in the unfortunate case of the Maize MON863. In that case the producing company (Monsanto) was obliged by a German Court to release the data, and I personally saw the amazingly poor statistical treatment utilized. In the second place, EFSA guidelines do not take into account the rapidly improving tools for risk assessment and do not carry out what is called "whole cycle analysis", looking at all possible direct and indirect effects of GMOs not only on human health, but also on environment and agriculture as has been rightly done in the present questionnaire. So, at the molecular level whole genome analyses putatively leading to "unintended effects" are never carried out and old fashioned Southern's are readily accepted in their place, proving the presence and integrity of the engineered construct but not the putative presence of other DNA fragments scattered into the receiving genome as found in many cases, for instance, by Svitashev and Somers (2001) and many others. This omission does not allow the screening of putative changes in host gene expression, the transcription of fusion RNAs and proteins, etc. (see Rosati et al. 2008). Moreover, epigenomic analyses are not requested, studies on the metabolomes and physiological changes, particularly in hormone patterns, the study of effects on the environment are limited to the possible weed resistance to herbicides, and so on. Finally, requested studies of GMO toxicity in rats are very poor and carried out for periods that are much too short. However, my feeling (not my scientific opinion due to the lack of data) is that health risks of transgenic food on the market now are limited, micro-RNAs may in theory block genes having complementary sequences. I think that the risks from blocks in genes relevant to human health is very low, but it may happen. It should be recalled from this point of view that not-aimed insertion of DNA into the receiving genomes is the main reason of the unfortunate failure of gene therapy in humans. The real danger being, also in this case, glyphosate and its adjuvants. As far as the future is concerned, I am really extremely worried about open air cultivation of plants which are transgenic for pharmaceuticals, because in that 
case cross-pollination with vaccines or other proteins could be really dangerous, as it could lead to unneeded pharmaceuticals in food. Of course, on the other hand, plants transgenic of proteins not liable to be produced by prokaryotes, if the plants are not to be grown in open air, may certainly be interesting.

3. When judging a novel technology the first question to be answered is whether the technology is really innovative and successful.

Which are the major technical advancements in plant genetic engineering since the release into the market of the first genetically modified products?

\section{P. Christou:}

The first GM crops on the market were engineered for herbicide tolerance; these were soon followed by plants engineered for pest resistance. More than 15 years later, almost all commercially approved GM crops still have one or both of these traits, and for the first time in 2009-2010, plants stacked with multiple traits were grown more widely than those with single traits. Indeed, July 2009 saw the commercial release of the most 'stacked' GM crop thus far, i.e. Smartstax corn, jointly developed by Monsanto and Dow AgroSciences, combining eight different herbicide and pest resistance traits.

Despite the rather limited scope of current commercial GM crops, the development pipeline is incredibly rich and diverse. Innovations in the development of GM crops fall into four major areas, which can be described as improved first-generation crops (focusing on input traits but using innovative approaches), novel second-generation crops (delivering better output traits), third-generation crops (delivering value added products) and technical developments such as the control of transgene expression (Farre et al. 2011a; Bai et al. 2011).

In the first category, several new approaches have been developed to achieve pest resistance in addition to the current reliance on Bt genes, because Bt genes do not exist to counter the effects of all known pests. Also, there is the potential for pest populations to evolve resistance to single Bt toxins (Christou et al. 2006; Ferry et al. 2006). As well, there are alternative protein toxins such as lectins that work against recalcitrant sap-sucking insects; novel approaches include the expression of toxin fusions (Mehlo et al. 2005) and the use of RNA interference by targeting genes essential for insect development (Huvenne and Smagghe 2010). A small number of commercial crops are resistant to diseases, such as virusresistant papaya, squash, plum and bean plants, and rice plants resistant to bacterial infections. Many additional GM crops resistant to various viral, bacterial and fungal diseases are under development, using a vast number of different approaches, such as enhancing natural plant defenses, the expression of pathogen proteins, the expression of plantproteins that repel specific pathogens and even the expression of mammalian antibodies that neutralize pathogens inside the plant (Collinge et al. 2010). Many concepts have also been developed that will help crops withstand harsh environments, especially drought, high levels of salinity, waterlogging and poor soil quality (Cominelli and Tonelli 2010).

Although first-generation crops benefit farmers mainly by allowing them to overcome biological and environmental extremes (biotic and abiotic stresses), the next breakthrough in GM agriculture will be the deployment of second-generation crops, where the benefits are targeted at consumers. The key examples here are Golden Rice, which produces enough $\beta$-carotene in the polished grain to ensure that consumers relying on a cereal diet do not suffer vitamin A deficiency (Potrykus 2010), and the multivitamin corn and high zeaxanthin corn produced in our laboratory (Naqvi et al. 2009, 2011a, b; Zhu et al. 2008). In multivitamin corn, three distinct metabolic pathways are modified to simultaneously enhance the levels of three key vitamins. The rapid progress of nutritionally enhanced GM crops through the development pipeline will save millions of lives and reduce the impact of malnutrition in the world's poorest areas (Zhu et al. 2007).

There has also been remarkable progress in the development of third-generation GM crops, which are not intended for human consumption but instead have valuable industrial uses (Naqvi et al. 2011a; Ramessar et al. 2008c). At the forefront are pharmaceutical crops producing proteins or small-molecules of medical relevance (Ma et al. 2003, 2005; Ramessar et al. 2008c). In our laboratory we have achieved the production of an HIV-neutralizing antibody in corn which could be used as a microbicide component to help prevent the spread of the virus (Ramessar et al. 2008b). The value of producing such molecules in plants rather than mammalian cells or bacteria as is usually the case is the reduced costs, the better safety profile (no human or animal pathogens, no endotoxins) and the massive production scale that can be achieved with little additional effort (Stoger et al. 2005). Also in this category are plants used to produce industrial raw materials (e.g. starch, rubber) and plants used to produce fuel (e.g. bioethanol, biodiesel). In both cases, it is important to avoid competition with food crops.

Finally, a variety of novel technologies have been developed to control transgene expression, e.g. spatiotemporal and inducible promoters (Peremarti et al. 2010), and to increase the precision of transgene integration into plants, e.g. transcriptional activator-like effector nucleases (TALENs) and zinc-finger nucleases (Weinthal et al. 2010).

Some might argue that the development pipeline discussed above is misleading because only four cultivated crops with the same two modifications have reached the 
market. Does this then mean that all the others have been failures? I would say that the answer is emphatically no. First, there are other products on the market that do not receive as much attention, e.g. virus-resistant rainbow papayas that have been consumed in the US for years and that have recently been approved in Japan, one of the most stringent markets. GM sweet corn is also approved for human consumption in the US and GM beans are now grown in Brazil. The problem with the adoption of novel GM crops is the huge cost of regulatory approvals (industry estimates suggest each new crop will cost \$US 100 million in development). This means that only major staple crops currently offer any hope of investors recovering their R\&D costs. Although the EU claims to defend a "knowledgebased bioeconomy", some patents covering glyphosatetolerant sugar beet expired before the cultivation of this crop was approved in Europe. On top of this, the activity of NGOs that oppose GM crops is often supported by public administrations and welcomed by the media, resulting in approved GM crops like Bt potato being rejected by the food industry to avoid campaigns against their brands. We can define them as technical and regulatory successes, but marketing failures, as happens in many other areas of the economy.

Golden Rice will soon be grown on a large scale in the Philippines. It has taken years to obtain regulatory approval and funding for this was raised only recently. Because Golden Rice does not directly benefit farmers, there was no incentive for industry to cover the approval costs. My opinion is that these costs should have been covered by government public health authorities, as they stand to lose the most from a population riven by vitamin A deficiency and they have the most to gain from the health benefits derived from this crop.

\section{Buiatti:}

After the development by M.D.Chilton in 1991 of the first method of plant genetic engineering through the usage of Agrobacterium tumefaciens, the first transgenic plant (tobacco), was produced in 1983 and a few years later Bt genes for resistance to insects and genes for the resistance to herbicides were introduced into crops. The first transgenic cultivar to enter the market was the Tomato Flavr Savr, resistant to rotting, in 1994, but it was very soon withdrawn, because of unexpected negative side effects of the transformation. In 1996 both insect resistant maize and RR soybean herbicide resistant plants were introduced into the market. As reported by Clive James in the annual review of cultivated GMPs in 2010, only four cultivated crop plants, still bearing the same two modifications, are in the market and have been widely commercialised (soybean, maize, cotton, canola). Therefore no new products have been released in the market with success, in spite of the many announced GMPs, and a few have been withdrawn from the market like the first one, the tomato Flavr Savr and the last one as far as I know, the so-called "Golden rice", of which a new cultivar producing more pro-vitamin A than the former is expected but has not been released. In the meantime, research intensity on the part of the leading companies has been decreasing as discussed by Schimmelpfennig et al. (2004). Obviously, this speaks very little for an innovative technology whose first products have been on the market for almost 15 years. The scientific reasons for these failures lie in the complexity of the plant system and the consequent "unintended effects" deriving from the aforementioned interactions between the inserted construct and the host plant. Of course this does not mean that new useful and efficient products could not be obtained, but this can occur only if new, reliable methods of control of the dynamics of the plant system are developed. Apparently and unfortunately, the leading companies do not seem interested in following this process, probably because, as discussed further in the answer to question 6 , incomes of leading companies derive from the control of the market, the intellectual property rights of the commercialised products, the stock exchange etc. and not from innovations in the field.

4. The import of affordable GM soybeans and GM corn from Brazil, USA, Argentina and other countries is pivotal in maintaining the competitiveness of the livestock farmers that satisfy the consumer's demand for meat, milk and eggs. This supply is allowed by EC approval and supported by positive case by case EFSA Scientific Opinions and up to 16 years of environmental compatibility. Since EFSA has issued a positive Opinion on the cultivation of GM crops in the EU, what reasons can be provided to discriminate against European farmers who are not allowed to cultivate the same GM crops that are imported and consumed from other continents?

\section{Buiatti:}

As discussed thoroughly also in the answer to question 6 , this question is misleading when it states that livestock farmers need GM-soybean They need soybean, but it need not necessarily be transgenic. (a) As shown by USDA data on productivity of soybean in the U.S.A soybean production per acre steadily increased from 1977 to 2007 and the speed of increase did not change with the introduction of GM plants in 1996. (b) From the nutritional point of view, as far as we know (see answer to question 2) no data are available showing better results in animal feeding in the case of GM compared with non GM soybean. The reasons most of world wide soybean production stems from GM plants is the economic advantage coming from a reduction 
in the needed manpower for herbicide spraying on herbicide resistant cultivars and the control of the market by the three large holdings: Monsanto, Dupont and Syngenta. In our case the average size of farms is of 5-6 hectares; the farms with the extant GMPs may be up to more than hundred thousand. So, while in large farms airplanes can be utilized to spray herbicides, certainly our farmers have to rely on manpower working directly in the field. So here and in most anti-GMO European regions there is no manpower advantage.

\section{P. Christou:}

There is no rational explanation for the EU's current de facto ban on the cultivation of GM crops while concurrently allowing the import of GM produce from the Americas to prop up the meat, poultry and dairy industries.

The EU is a net importer of agricultural raw materials and $55 \%$ of these imports come from ten countries, most of which have GM-based agricultural industries (Sabalza et al. 2011). Brazil, the United States and Argentina occupy the top three positions and are also the world's largest GM producers, and almost all of the products imported from these countries are GM. The EC has recently proposed to give Member States the freedom to veto the cultivation of GM crops on their own territory without needing to provide any scientific evidence relating to new risks (European Commission 2010b), ostensibly to prevent tactical voting leading to EU-wide bans (Casassus 2011). However, although the proposed amendment will allow member states to adopt measures against the cultivation of GM crops, they will not be allowed to prohibit the import or marketing of authorized GM products from elsewhere, which means that EU markets are likely to be flooded with imported GM products that could just as easily be homegrown. This is clearly a ludicrous position, which simultaneously restricts the freedom of EU farmers to grow the crops they choose and forces them to accept GM animal feed from abroad (Sabalza et al. 2011).

Even so, the import of GM products is also over-regulated, and this is particularly apparent in the EU's treatment of imported corn and soybean from the United States, which has radically different regulations concerning adventitious presence limits, traceability and labeling (Ramessar et al. 2008a). Although the EU is deficient in feed protein and is ultimately dependent on soybean imports, the complex and onerous process for approving imported GM products has discouraged overseas traders, resulting in a decline in imports from $\$ 2.8$ billion in 1997 to $\$ 1.9$ billion in 2008 (USDA 2009). This is despite EFSA issuing multiple Scientific Opinions declaring that GM products are safe and (as discussed above) the complete absence of any adverse effects of GM crops anywhere in the world throughout the $15+$ years of cultivation.
A critical point is that if the EU continues to obstruct GM agriculture, it will force farmers to use environmentally hazardous, expensive and unsustainable agricultural practices, spend unnecessary resources on fossil fuels and agrochemicals, while at the same time importing GM products from the Americas. This policy will also discourage research and drive researchers overseas where the value chain can be realized in terms of released GM crops. Within the EU, researchers working on GM plants know that the best they can expect for their products is greenhouse cultivation, and that despite their benefits, GM crops are unlikely to be deployed in any setting where they could perform a useful function. Here the EU policy on GM crops is attacking its own foundations as a competitive bioeconomy because with one hand the EC offers funding for innovative biotech research and values (or even requires) the participation of small- to medium-sized enterprises (SMEs) and large industry partners, while with the other they prevent the same companies from realizing the value of their development pipeline. Many individual scientists and large companies with ambitious GM research projects have moved abroad to continue their work, and promising European SMEs have been unable to find investment partners (The Guardian 2003, 2004). No significant investment in Europe is likely unless companies can recoup their R\&D costs by selling their products to farmers. The attitude of European policymakers reveals the immense divide between the rational evaluation of science and business, and the panicky, expedient politics pandering to a populist media and activists (Farre et al. 2010, 2011a, b).

5. It is known that uncontrolled attacks of corn borers (Ostrinia, Sesamia) facilitate the growth of Fusarium moulds in corn grains leading to the accumulation of dangerous levels of fumonisins. The use of Bt corn has been proven to decrease/eliminate fumonisins from corn, and this is a contaminant that has led to European safety alerts and corn product recalls. What is your recommendation to reduce/eliminate mycotoxins in corn grain?

\section{Buiatti:}

Of course there are more conventional methods to stop the attacks both through the use of chemicals and of biological agents, but certainly insect resistance may be a valid one when and if the plant is resistant to all corn borers at the same time and not only one of them, and of course the borers are not naturally selected for resistance to $\mathrm{Bt}$ toxins. Everybody who has been working in plant breeding knows that both in the case of "traditional" breeding and genetic engineering, insect resistant crops are resistant only for a short time because insects acquire resistance to the toxins in the case of genetic engineering or other genes 
leading to resistance in traditionally bred cultivars. This is happening in the case of maize in the USA and induced the Government to rule the maintenance of areas with susceptible plants to partially overcome this problem. In the case of cotton in China, the resistance to the boll worm induced the multiplication of more than a hundred competitor species, and therefore the amount of insecticides rose to levels never reached with non-boll worm resistant crops

\section{P. Christou:}

Fumonisins are mycotoxins produced by Fusarium molds when they colonize cereal grains. They are toxic to humans, particularly affecting liver and kidney functions, causing esophageal cancer, increasing HIV transmission rates (Williams et al. 2010) and inducing neural tube defects such as spina bifida in utero (Marasas et al. 2004; Torres et al. 2007). The maximum tolerable daily intake is $2 \mu \mathrm{g} / \mathrm{kg}$ body weight as stated in EC Regulation 1881/2006. Many nations have established regulatory standards stating maximum tolerance levels for mycotoxins in food and feed. Therefore, aside from the health risks described above, mycotoxin contamination can also reduce the price paid for food crops, or in extreme cases, can cause market rejection of entire food or feed shipments ( $\mathrm{Wu}$ et al. 2004; Wu 2006). The maximum permitted daily intake of fumonisins was doubled in EC Regulation 1126/2007 in recognition of the fact that recommended levels cannot be achieved under some circumstances. This is not a recommended practice, nor is it consistent with other EC decisions including the application of the precautionary approach, because several corn herbicides have been banned in the EU at contamination levels far lower than allowed for fumonisins (Wu 2006).

There is a clear relationship between corn borer damage and unsafe levels of fumonisins in raw corn, reflecting the penetration of damaged corn kernels by the fungus (Munkvold et al. 1997; Ariño 2009; Escobar and Quintana 2008; EFSA 2005). Any method that reduces insect damage in corn also reduces the risk of fungal contamination, but foliar Bt sprays are not sufficient because the corn borers are protected inside the cob (Sanahuja et al. 2011). Bt corn confers resistance to corn borers and therefore reduces mycotoxin contamination. In Europe and elsewhere, field trials of Bt corn on 288 separate test sites have shown that harvested kernels have significantly lower fumonisin levels than non-Bt counterparts, with fumonisin concentrations in Bt grain usually lower than $4 \mu \mathrm{g} / \mathrm{kg}$ and often below $2 \mu \mathrm{g} / \mathrm{kg}$ (Wu 2006). Interestingly, $31 \%$ of fumonisin contamination alerts in Spanish corn grain represent organically-grown corn, which represents less than $1 \%$ of the area under cultivation, and the other $69 \%$ represent conventional corn. No alerts have been raised for borer- resistant GM corn, which represents $21 \%$ of the cultivated area. This information comes directly from the Spanish Ministry of the Environment (http://www.efsa.europa. eu/en/events/documents/gmo090914-p13.pdf).

Similar indications come from import checks in Italy where contamination in Bt corn is consistently registered as lower than conventional corn. The benefit of Bt corn in terms of the reduction of mycotoxin damage has been virtually ignored in policy debates, despite its positive economic impact in the US and its effect on both health and the economy in developing countries (Wu et al. 2004; $\mathrm{Wu}$ 2006). In my opinion its cultivation should be mandatory in EU regions where corn borers are endemic, but the cultivation of $\mathrm{Bt}$ corn is subject to a de facto ban across large areas of the EU and particularly for nations such as Italy (Table 1) and France where fumonisin toxicity is prevalent (Pietri and Piva 2000; Masoero et al. 1999; Folcher et al. 2010).

6. Roughly one quarter of the Earth's terrestrial surface is now under cultivation with more land converted to crop production in the 30 years after 1950 than in the previous 150 years. Given this picture, economic and social concerns present critical challenges to agriculture in the next decades. Farm profitability, viability of rural communities, fair trade and agricultural labor represent significant issues. Which are the advantages of GM crops for agriculture from the economic and social points of view?

\section{P. Christou:}

GM crops provide tools that are compatible with many of the other approaches used currently to increase food production, while reducing the environmental footprint of agriculture and increasing the affordability of crops (Christou and Twyman 2004). The socioeconomic advantages of GM crops are demonstrated by the consistent growth in adoption since the first commercial releases (James 2010) combined with ample evidence of greater farm profitability in both developed economies like the US (Smale et al. 2009) and emerging economies like India (Subramanian and Qaim 2010). There has been considerable debate about economic potential of GM crops in developing countries (Park et al. 2011), and an extensive analysis carried out by Brookes and Barfoot (2010) showed that approximately two thirds of the net benefits of GM agriculture go to farmers, and one third to the seed supply chain. In the case of Bt crops, these benefits include yield improvements, higher revenues and lower pesticide costs, which more than compensate for the higher seed prices.

Overall, the available evidence confirms that in both developed and developing countries, the adoption of GM crops can increase the farmer's income. The increase in 
Table 1 Fumonisin content in ppb $(\mu \mathrm{g} / \mathrm{kg})$ in Italian field trials

\begin{tabular}{llll}
\hline Author & Years & Bt corn & Non-Bt corn \\
\hline Pietri and Piva (2000) & 1997 & 2.021 & 19.759 \\
Pietri and Piva (2000) & 1998 & 5.448 & 31.632 \\
Pietri and Piva (2000) & 1999 & 1.394 & 3.902 \\
Masoero et al. (1999) & 1997 & 1.970 & 20.050 \\
\hline
\end{tabular}

income to small-scale farmers in developing countries can have a direct impact on poverty alleviation and quality of life, a key component of sustainable development. Bennett et al. (2006) compared the performance of $B t$ and non- $B t$ cotton in resource-poor smallholder cotton farm plots in India and South Africa. Their results demonstrated that in many agricultural environments the adopters of $B t$ cotton benefit in terms of higher yields, reduced labor and pesticide use, and ultimately higher gross margins per hectare, leading them to conclude that 'that the smallest producers are shown to have benefited from adoption of the $B t$ variety as much as, if not more than, larger producers.'

Even where economic issues of coexistence come into play, smallholder farmers usually trade their GM and nonGM crops together, using cooperatives or local dealers that also provide seeds and other inputs. In this way, in cornborer endemic areas where Bt-corn is approved and its use makes sense, it is common to see $50-80 \%$ of farmers using GM corn, without isolation barriers and only the required refuges of non-GM corn to delay the appearance of resistant corn borer strains. These jointly marketed products are labelled as GM corn even if only $50-80 \%$ of the grain is transgenic.

The social impact of GM agriculture is intertwined with the economic benefits because the higher margins generated by GM crops help efforts to alleviate poverty, and therefore provide better access to food, medicine and education, enhancing the social dimension of sustainability (Yuan et al. 2011). Second- and third-generation GM crops have been developed to address these issues directly by improving nutrition or providing inexpensive drugs, but even the first-generation crops have indirectly led to improvements simply by increasing the profitability of farms and empowering the smallholders in a socioeconomic context. There have also been more direct health benefits of GM agriculture by reducing exposure to pesticides (Brimner et al. 2005; Knox et al. 2006), changing the patterns of herbicide use to favor those with lower toxicity such as glyphosate, and as mentioned above, reducing the exposure of populations to mycotoxins (Munkvold et al. 1999). Work is also well advanced in the development of GM crops that will have a direct impact on health, e.g. those with reduced allergens (Chu et al. 2008), higher levels of proteins and carbohydrates (reviewed by Newell-
McGloughlin 2008), and higher levels of essential amino acids, essential fatty acids, vitamins and minerals (Damude and Kinney 2008), the most prevalent examples being Golden Rice (Potrykus 2010), multivitamin corn (Naqvi et al. 2009; Zhu et al. 2008), and high zeaxanthin corn (Naqvi et al. 2011b). GM agriculture can therefore have a significant impact on both industrialized and developing economies by increasing farm profit margins, as well as by contributing to the social dimension of sustainable development by reducing the handling and use of pesticides, exposure to adventitious mycotoxins and, ultimately, by directly addressing the causes of hunger and malnutrition.

\section{Buiatti:}

As I mentioned before, the productivity of maize and soybean, according to USDA data from 1977 to 2007, did not increase from the introduction of GM-crops but probably from the improvements in management and conventional breeding. Moreover, in the case of $\mathrm{Bt}$, the advertised reduction in the usage of insecticides did not happen because of the selection of Bt resistant insects and the fast reproduction of other parasite species than those killed by Cry toxins, as we shall discuss later. Also the cost of herbicides has not been obviously reduced, the very aim of herbicide resistant plant introduction being an increased number of treatments also during plant growth. Therefore, as already mentioned, the economic advantage of the introduction of herbicide resistance traits is the reduction of manpower costs, all this favouring farms of large dimensions with an increase of the input of capital and a decrease of labour leading to the exit from the systems of subsistence agriculture due to lack of capital. The reasons of the outstanding success of GM crops particularly in the USA, Canada and Latin-American countries can be understood only if we look at the structure of the market for the four mentioned crops. In the first place, (for a good review, see Howard 2009) since the nineteen-nineties, a very fast concentration process has occurred, few multinational companies gaining the control of large part of the food related market, the first four companies controlling $59 \%$ of the pesticides, $56 \%$ of the seed and practically all GMPs. This process has been favoured by the extension, within the TRIPS agreement, of industrial patents to living objects and processes and by the change in the UPOV cancelling both the so-called farmer's and breeder's rights. To give an idea of the power given to the holders of patents, already in 1995, according to the World Patent Index, Bt maize was covered by 440 patents, $88 \%$ of which were owned by industry. Nowadays, three companies, through IPRs, have the control not only of GMPs but also of innovations related to other steps of the food production chain. That follows from the fact that all the leading companies, before GMO production, were agro-chemical industries and since 
the 1990s acquired control of chemical, pharmaceutical and seed companies. For instance, Monsanto, a herbicide producer in the sixties, acquired Pharmacia and Upjohn and the seed industries Cargill, Dekalb Genetics Corporation, Delta and Pine Land, Seminis, and Holden Foundation Seeds and controls more than 200 seed companies in India, China and Brazil. Dupont, on the other hand, has acquired the seed company Pioneer High Bred, while Syngenta derived from the fusion between Novartis agriculture and Zeneca. The power of the leading companies is also based on the presence in public control agencies and in the editorial boards of international scientific journals, as thoroughly discussed by Glover (2009), on behalf of the British E.S.R.C., in his critical synthesis of the scientific literature concerning Bt-Cotton in China, India, South Africa. For this reason, according to Glover, it is not widely known that in China BT cotton is useful only in the case of heavy presence of the boll-worm, that insecticide consumption does not decrease (Wang 2008). Nor it is known that in India, in the regions of Andhra Pradesh and Maharashtra, the presence of 150 different species of insects obliged the farmers to increase the input of pesticides while the price of cotton was decreasing (Ramasundaram et al. 2007). In Latin America, on the other hand, problems derived from the transformation of local subsistence agricultures based on the production of food into industrial farming, aimed at the export of soybean for animal feeding in developed countries. In Argentina, Brazil, Paraguay and, lately also Uruguay, many small farms were purchased and replaced by large ones, up to 100.000 hectares. For this reason, in Argentina, soybean production rose from 1996 to 2004 by $11.8 \%$, that of wheat being $-2.3 \%$ lower, potato $-3.3 \%$, millet $-19.1 \%$ and labour also being reduced by $50 \%$ (Gallacher 2009). In Brazil, farmers were expelled with the use of force and the big soy producers from Argentina along with Japanese and German jobbers control $76 \%$ of Paraguay soybean producers, thus further reducing revenues and jobs. Of course, in all these cases the economic and social disasters deriving from the introduction of GMPs were not due by any means to genetic engineering techniques as such, but by the structure of the market where for the first time living objects could be covered by industrial patents through economical and political agreements between the producer companies and governments and under the rules of the WTO. However, it is worth stressing here that, as mentioned before, the advantages of GMPs only favoured large farms and the multinational companies, small farmers leaving the fields and the seeds of a number of relevant crops and losing languages and traditional knowledge in the favelas of several countries (see the data in the website of Terralingua, an NGO working on bio-linguistic problems).
7. The possible economic advantages of GMOs in an agricultural context have been discussed extensively. In this respect GMOs have been viewed by some as an effective way to meet the energy needs of the most vulnerable, malnourished populations in developing countries. Do the available results provide indications for a possible role of GMOs in improving food quality, therefore providing specific nutritional advantages also in wealthy population groups?

\section{Buiatti:}

The improvement of nutritional quality of crops has been one of the main objectives of plant genetic engineering as, in theory, the modification of metabolic pathways could lead to the qualitative and quantitative improvement of specific nutritional components. Rather unfortunately, due to the network structure of plant metabolism implying that a change in one node will affect other components, the results have been far from successful. As far as I remember, the only putative success has been obtained with the so-called "Golden Rice", a producer of pro-vitamin A which was released into the market but soon withdrawn because of the low level of production of the molecule. This happened a few years ago and we are now waiting for new cultivars with improved production. Unfortunately, as already discussed, the research intensity of GMO producers has been lower and lower, thus slowing the release of really innovative cultivars in all fields.

\section{P. Christou:}

GMOs certainly have the potential to provide nutritional advantages for wealthy population groups, despite the controversy about GM agriculture in Europe discussed elsewhere in this article. One of the important benefits of transgenic crops is the ability to generate more nutritious varieties, and although these are currently targeted towards developing countries with the worst malnutrition levels, they offer clear benefits to all sectors of the population. Even in Europe there is a surprisingly large malnourished population, which has arisen not only through the impact of poverty but also through ignorance and poor lifestyle choices. Malnourishment is particularly rife in the elderly population because one of the consequences of aging is a progressive loss of the ability to absorb nutrients (Ljungqvist et al. 2010).

EU policies on food and nutrition are described in the European Commission White Paper on Food Safety and the Program for Public Health (European Commission 2000). The fortification of processed food and agronomic biofortification using nutrient-rich fertilizers have been applied successfully to overcome the lower levels of nutrients in the UK and Finland (Lyons et al. 2003; Broadley et al. 2006), but there are also several sectors of the wealthy 
population where nutritional and food quality needs could be met through the use of transgenic crops. The most significant is the biofortification of cereals, legumes, fruits and vegetables with iron to combat anemia resulting from iron deficiency caused by poor dietary habits (Lucca et al. 2002). This is because traditional routes such as iron supplements can be inefficient because of poor compliance (Darnton-Hill and Nalubola 2002; Gómez-Galera et al. 2010). Another interesting example is the potential to increase the carotenoid levels in cereals such as maize to address macular degeneration in the elderly. Most people know that $\beta$-carotene is required in the diet as a source of vitamin $A$, but few recognize the importance of other carotenoids such as lutein and zeaxanthin, which are required in the eye to prevent damage caused by strong light (Landrum and Bone 2001). A diet rich in these molecules has been linked with eye health in the ageing population and biofortification at source would be an advantageous way to address this growing problem (Hammond et al. 1997; Landrum et al. 1997).

Another valuable approach is the fortification of staple foods such as cereals with polyunsaturated fatty acids currently only found in fish. The metabolic pathways that lead to omega fatty acids are understood and can be recreated in plants (Ye and Bhatia 2012). The development of cereal products enriched with these essential fatty acids would increase the general health of the population by providing essential nutrients to those who rarely eat fish, and would also reduce pressure on fish stocks as a sole source of this nutrient.

The controversy surrounding mycotoxin levels in maize is discussed in another section, but it is worth pointing out here that this is a problem that faces all consumers, not just those in developing countries, so the ability to grow Bt maize commercially in Europe would, again, provide consumers from all population groups with higher quality food and would at the same time remove the need to import exactly the same products from abroad (Folcher et al. 2010).

Finally, there is a great deal of interest in the development of functional foods that provide added-value health benefits to consumers as well as calories (e.g. antioxidants and other health-promoting compounds). Since the metabolic pathways leading to many of these valuable molecules are now being unraveled, it is likely that the first generation of biofortified foods containing essential nutrients will be followed by a second wave of luxury goods aimed at the higher-income sectors, comprising food products with enhanced levels of health-promoting compounds (Zhu et al. 2012).

\section{Conclusions}

There is obviously no final conclusion of this debate, which is likely to continue for years. We can foresee that plant biotechnology will potentially be able to provide several benefits and address many challenges in food production. However, it is also crucial that the release of GM crops in the environment does not bear new risks and irretrievable consequences and/or threats for human health.

However, within this framework, it would be desirable to reach a global harmonization of regulation and legislation of GM crops in order to face the ongoing globalisation of agricultural production. GM crops, in fact, are going to become significant in world crop production as the cultivation of GM crops in the world in 2011 reached 160 million hectares ( $+8 \%$ with respect to 2010 , a 94 -fold increase with respect to 1996) in 29 countries worldwide. According to the International Service for the Acquisition of Agri-biotech Applications (James 2011), 16.7 million farmers grew biotech crops in 2011 , over $90 \%$ were small resource farmers in developing countries ( 7 million in China and 7 million in India), and they collectively planted 14.5 million hectares of GM crops. The US is the lead producer of GM crops, with 69.0 million hectares (maize, soybean, cotton, canola, sugarbeet, alfalfa, papaya, squash) followed by Brazil (30.3 million hectares, soybean, maize, cotton), Argentina (23.7 million hectares, soybean, maize, cotton), India (10.6 million hectares, cotton), Canada (10.4 million hectares, canola, maize, soybean, sugarbeet) and China (3.9 million hectares, cotton, papaya, poplar, tomato, sweet pepper). In Europe, six EU countries (Spain, Portugal, Czechia, Poland, Slovakia and Romania) planted 114.490 hectares of $\mathrm{Bt}$ maize $(+26 \%$ as respect to 2010), with Spain growing $85 \%$ of the total in the EU.

Obviously, this paper is not aimed at reaching any conclusion on this controversial matter. However, we hope that this face-to-face between two almost opposite positions can contribute to the discussion related to this delicate aspect of agro-food science.

It is worth stating that the debates on international markets, economical issues, crop productivity, ethical aspects and environmental concerns are indisputably important, but only keeping in mind that the first, most imperative issue is to warrant a reliable, safe and healthy nutrition to the population.

Acknowledgments Research at the Universitat de Lleida is supported by MICINN, Spain (BFU2007-61413); European Union Framework 7 Program-SmartCell Integrated Project 222716; European Union Framework 7 European Research Council IDEAS Advanced Grant Program-BIOFORCE; COST Action FA0804: Molecular farming: plants as a production platform for high value proteins; Centre CONSOLIDER on Agrigenomics funded by MICINN, Spain. All research programs in our laboratory are supported exclusively through public funds.

Open Access This article is distributed under the terms of the Creative Commons Attribution Noncommercial License which permits any noncommercial use, distribution, and reproduction in any medium, provided the original author(s) and the source are credited. 


\section{References}

Ariño A (2009) Influence of agricultural practices on the contamination of corn by fumonisin mycotoxins. J Food Protect 72:898-902

Bai C, Twyman RM, Farre G, Sanahuja G, Christou P, Capell T, Zhu C (2011) A golden era-pro-vitamin A enhancement in diverse crops. In Vitro Cell Dev Biol Plants 47:205-221

Barriuso J, Marín S and Mellado RP (2010) Effect of the herbicide glyphosate on glyphosate-tolerant corn rhizobacterial communities: a comparison with pre-emergency applied herbicide consisting of a combination of acetochlor and terbuthylazine. Environ Microbiol 12(4):1021-1030

Barriuso J, Valverde JR, Mellad RP (2011a) Effect of the herbicide glyphosate on the culturable fraction of glyphosate-tolerant corn rhizobacterial communities using two different growth media. Microbes Environ 26:332-338

Barriuso J, Marín S, Mellado RP (2011b) Potential accumulative effect of the herbicide glyphosate on glyphosate-tolerant corn rhizobacterial communities over a three-year cultivation period. PLoS One 6(11):e27558. doi:10.1371/journal.pone.0027558

Batista R, Oliveira MM (2009) Facts and fiction of genetically engineered food. Trends Biotechnol 27:277-286

Beckie HJ (2009) Field trials prove speed of herbicide resistance. Western Producer, 1 Oct 2009, p 65

Belmonte J (1993) Estudio comparativo sobre la influencia del laboreo en las poblaciones de vertebrados en la campiña de Jerez. Bol San Veg Plagas 19:211-220

Bennett R, Morse S, Ismael Y (2006) The economic impact of genetically modified cotton on South African smallholders: yield, profit and health effects. J Dev Stud 42:662-677

Brimner TA, Gallivan GJ, Stephenson GR (2005) Influence of herbicide-resistant canola on the environmental impact of weed management. Pest Manag Sci 61:47-52

Broadley MR, White PJ, Bryson RJ, Meacham MC, Bowen HC, Johnson SE, Hawkesford MJ, McGrath SP, Fang-Jie Z, Breward N, Harriman M, Tucker M (2006) Biofortification of UK food crops with selenium. Proc Nutr Soc 65:169-181

Brookes G, Barfoot P (2009) Global impact of biotech crops: income and production effects, 1996-2007. AgBioForum 12:184-200

Brookes G, Barfoot P (2010) GM crops: global socio-economic and environmental impacts 1996-2008. PG Economics Ltd, Dorchester

Casassus B (2011) EU parliament votes to allow restrictions on GM food. Nature News Blog, 6 July 2011 (http://blogs.nature. com/news/2011/07/eu_parliament_votes_to_allow_r.html)

Castaldini M, Turrini A, Sbrana C, Benedetti A, Marchionni M, Mocali S, Fabiani A, Landi S, Santomassimo F, Pietrangeli B, Nuti MP, Miclaus N, Giovannetti M (2005) Impact of Bt corn on rhizospheric and soil eubacterial communities and on beneficial mycorrhizal symbiosis in experimental microcosms. Appl Environ Microbiol 71:6719-6729

Christou P, Twyman RM (2004) The potential of genetically enhanced plants to address food insecurity. Nutr Res Rev 17:23-42

Christou P, Capell T, Kohli A, Gatehouse JA, Gatehouse AMR (2006) Recent developments and future prospects in insect pest control in transgenic crops. Trends Plant Sci 11:302-308

Chu Y, Faustinelli P, Ramos ML, Hajduch M, Stevenson S, Thelen JJ, Maleki SJ, Cheng H, Ozias-Akins P (2008) Reduction of IgE binding and nonpromotion of Aspergillus flavus fungal growth by simultaneously silencing Ara h 2 and Ara h 6 in peanut. J Agric Food Chem 56:11225-11233

Collinge DB, Jørgensen HJ, Lund OS, Lyngkjaer MF (2010) Engineering pathogen resistance in crop plants: current trends and future prospects. Annu Rev Phytopathol 48:269-291
Cominelli E, Tonelli C (2010) Transgenic crops coping with water scarcity. Nat Biotechnol 27:473-477

Conner AJ, Glare TR, Nap JP (2003) The release of genetically modified crops into the environment part II. Plant J 33:19-46

Crawley MJ, Brown SL, Hails RS, Kohn DD, Rees M (2001) Biotechnology: transgenic crops in natural habitats. Nature 409:682-683

Damude HG, Kinney AJ (2008) Engineering oilseed plants for a sustainable, land-based source of long chain polyunsaturated fatty acids. Lipids $42: 179-185$

Darnton-Hill I, Nalubola R (2002) Fortification strategies to meet micronutrient needs: successes and failures. Proc Nutr Soc 61:231-241

EC Research (2001) EC-sponsored research on safety of genetically modified organisms: a review of results: http://europa.eu.int/ comm/research/quality-of-life/gmo/

EFSA (2005) Opinion of the scientific panel on contaminants in food chain on a request from the commission related to fumonisins as undesirable substances in animal feed. EFSA J 235:1-32

EFSA (2010) Guidance on the environmental risk assessment of genetically modified plants. EFSA J 8:1879

Escobar J, Quintana J (2008) Reducción de riesgos sanitarios con el cultivo de un maíz transgénico. Libro de Resúmenes XIII Congreso Anual en Ciencia y Tecnología de los Alimentos, pp 29-31

European Commission (2000) White paper on food safety

European Commission (2010) A decade of EU-funded GMO research. Food, agriculture \& fisheries \& biotechnology, European Research Area, European Commission, Brussels, p 18

European Commission (2010) Memo 10/325: Questions and answers on the EU's new approach to the cultivation of GMOs. European Commission, Brussels

Farre G, Ramessar K, Twyman RM, Capell T, Christou P (2010) The humanitarian impact of plant biotechnology: recent breakthroughs vs bottlenecks for adoption. Curr Opin Plant Biol 13:219-225

Farre G, Bai C, Twyman RM, Capell C, Christou P, Zhu C (2011a) Nutritious crops producing multiple carotenoids-a metabolic balancing act. Trends Plant Sci 16:532-540

Farre G, Twyman RM, Zhu C, Capell T, Christou P (2011b) Nutritionally enhanced crops and food security: scientific achievements versus political expediency. Curr Opin Biotechnol $22: 245-251$

Ferry N, Edwards MG, Gatehouse JA, Capell T, Christou P, Gatehouse AMR (2006) Transgenic plants for insect pest control. A forward looking scientific perspective. Transgen Res 15:13-19

Folcher L, Delos M, Marengue E, Jarry M, Weissenberger A, Eychenne N, Regnault-Roger C (2010) Lower mycotoxin levels in Bt corn grain. Agron Sustain Dev 30:711-719

Gallacher M (2009) The changing structure of production: argentine agriculture 1988-2002, Universidad del CEMA, Buenos Aires, Documento de trabajo 415

Giovannetti M, Sbrana C, Turrini A (2005) The impact of genetically modified crops on soil microbial communities. Biol Forum 98:393-418

Glover D (2009) Undying promise: agricultural biotechnology's propoor narrative, ten years on. STEPS Centre ESRC, UK

Gómez-Galera S, Rojas E, Sudhakar D, Zhu C, Pelacho AM, Capell T, Christou P (2010) Critical evaluation of strategies for mineral fortification of staple food crops. Transgenic Res 19:165-180

Gressel J (2002) Molecular biology of weed control. Taylor and Francis, Abington, p 520

Gressel J (2008) Genetic glass ceilings-transgenics for crop biodiversity. Johns Hopkins University Press, Baltimore, p 461 
Gressel J (2012) Containing and mitigating transgene flow from crops to weeds, to wild species, and to crops. In: Altman A, Hasegawa PM (eds) Plant biotechnology and agriculture: prospects for the 21st century. Elsevier Press, NY, pp 509-523

Hammond BR Jr, Johnson EJ, Russell RM, Krinsky NI, Yeum KJ, Edwards RB, Snodderly DM (1997) Dietary modification of human macular pigment density. Invest Ophthalmol Vis Sci 38:1795-1801

Hare PD, Chua NH (2002) Excision of selectable marker genes from transgenic plants. Nat Biotechnol 20:575-580

Howard PH (2009) Visualizing consolidation in the global seed industry. Sustainability 1(4):1266-1287

Huber DM (2010) Agro-chemical and crop nutrient interactions: current update. Proc Fluid Fert Forum Scottsdale 27:1-13

Hutchison WD, Burkness EC, Mitchell PD, Moon RD, Leslie TW, Fleischer SJ, Abrahamson M, Hamilton KL, Steffey KL, Gray ME, Hellmich RL, Kaster LV, Hunt TE, Wright RJ, Pecinovsky K, Rabaey TL, Flood BR, Raun ES (2010) Areawide suppression of European corn borer with Bt corn reaps savings to non-Bt corn growers. Science 330:222-225

Huvenne H, Smagghe G (2010) Mechanisms of dsRNA uptake in insects and potential of RNAi for pest control: a review. J Insect Physiol 56:227-235

Icoz I, Stotzky G (2008) Fate and effects of insect-resistant Bt crops in soil ecosystems. Soil Biol Biochem 40:559-586

James C (2010) Global status of commercialized biotech/GM crops: 2009. ISAAA Brief 41-2009. ISAAA, Ithaca

James C (2011) Global status of commercialized biotech/GM crops: 2011. ISAAA Brief 43-2011. ISAAA, Ithaca

Kessler C, Economidis I (2001) EC-sponsored research on safety of genetically modified organisms. European Commission. Community Research

Knox OGG, Vadakattu GVSR, Gordon K, Lardner R, Hicks M (2006) Environmental impact of conventional and Bt insecticidal cotton expressing one and two Cry genes in Australia. Aust J Agr Res 57:501-509

Kremer RG, Means NE (2009) Glyphosate and glyphosate-resistant crop interactions with rhizosphere microorganisms. Eur J Agron 31:153-161

Landrum JT, Bone RA (2001) Lutein, zeaxanthin, and the macular pigment. Arch Biochem Biophys 385:28-40

Landrum JT, Bone RA, Joa H, Kilburn MD, Moore LL, Sprague KE (1997) A one year study of the macular pigment: the effect of 140 days of a lutein supplement. Exp Eye Res 65:57-62

Ljungqvist O, Gossum AV, Sanz ML, Man F (2010) The European fight against malnutrition. Clin Nutr 29:149-150

Lucca P, Hurrell R, Potrykus I (2002) Fighting iron deficiency anemia with iron-rich rice. J Am Coll Nutr 21:184S-190S

Lyons G, Stangoulis J, Graham R (2003) High-selenium wheat: biofortification for better health. Nutr Res Rev 16:45-60

Ma JKC, Drake PMW, Christou P (2003) The production of recombinant pharmaceutical proteins in plants. Nat Rev Genet 4:794-805

Ma JKC, Barros E, Bock R, Christou P, Dale PJ, Dix PJ, Fischer R, Irwin J, Mahoney R, Pezzotti M, Schillberg S, Sparrow P, Stoger E, Twyman RM (2005) Molecular farming for new drugs and vaccines. Current perspectives on the production of pharmaceuticals in transgenic plants. EMBO Rep 6:593-599

Marasas et al (2004) Fumonisins disrupt sphingolipid metabolism, folate transport, and neural tube development in embryo culture and invivo: a potential risk factor for human neural tube defects among populations consuming fumonisin-contaminated corn. J Nutr 134:711-716

Masoero F, Moschini M, Rossi F, Prandini A, Pietri A (1999) Nutritive value, Mycotoxin contamination and in vitro rumen fermentation of normal and genetically modified corn (cry 1A(b)) grown in northern Italy. Maydica 44:205-209
Mehlo L, Gahakwa D, Nghia PT, Loc NT, Capell T, Gatehouse JA, Gatehouse AMR, Christou P (2005) An alternative strategy for sustainable pest resistance in genetically enhanced crops. Proc Natl Acad Sci USA 102:7812-7816

Morris HS, Spillane C (2010) EU GM crop regulation: a road to resolution or a regulatory roundabout? Symposium on the EU's GMO reform. Eur J Risk Reg 4:359-369

Munkvold GP, Hellmich RL, Showers WB (1997) Reduced Fusarium ear rot and symptomless infection in kernels of corn genetically engineered for European corn borer resistance. Phytopathology 87:1071-1077

Munkvold GP, Hellmich RL, Rice LG (1999) Comparison of fumonisin concentrations in kernels of transgenic Bt corn hybrids and non-transgenic hybrids. Plant Dis 81:556-565

Nap JP, Metz PLJ, Escaler M, Conner AJ (2003) The release of genetically modified crops into the environment part I. Plant $\mathbf{J}$ 33:1-18

Naqvi S, Zhu C, Farre G, Ramessar K, Bassie L, Breitenbach J, Perez Conesa D, Ros G, Sandmann G, Capell T, Christou P (2009) Transgenic multivitamin corn through biofortification of endosperm with three vitamins representing three distinct metabolic pathways. Proc Natl Acad Sci USA 106:7762-7767

Naqvi S, Ramessar K, Farre G, Sabalza M, Miralpeix B, Twyman RM, Capell T, Christou P, Zhu C (2011a) High value products from transgenic corn. Biotechnol Adv 29:40-53

Naqvi S, Zhu C, Farre G, Sandmann G, Capell T, Christou P (2011b) Synergistic metabolism in hybrid corn indicates bottlenecks in the carotenoid pathway and leads to the accumulation of extraordinary levels of the nutritionally important carotenoid zeaxanthin. Plant Biotechnol J 9:384-393

Newell-McGloughlin M (2008) Nutritionally improved agricultural crops. Plant Physiol 147:939-953

Park RJ, McFarlane I, Phipps RH, Ceddia G (2011) The role of transgenic crops in sustainable development. Plant Biotechnol J 9:2-21

Peremarti A, Twyman RM, Gomez-Galera S, Naqvi S, Farre G, Sabalza M, Miralpeix B, Dashevskaya S, Yuan D, Ramessar K, Christou P, Zhu C, Bassie L, Capell T (2010) Promoter diversity in multigene transformation. Plant Mol Biol 73:363-378

Pietri A, Piva G (2000) Occurrence and control of mycotoxins in corn grown in Italy. Proceedings of the VI international feed production conference, pp 226-236, Piacenza, Nov 27-28

Potrykus I (2010) Lessons from the 'Humanitarian Golden Rice' project: regulation prevents development of public good genetically engineered crop products. Nat Biotechnol 27:466-472

Prischl M, Hackl E, Pastar M, Pfeiffer S, Sessitsch A (2012) Genetically modified $\mathrm{Bt}$ corn lines containing cry3Bb1, cry $1 \mathrm{~A} 105$ or cry $1 \mathrm{Ab} 2$ do not affect the structure and functioning of root-associated endophyte communities 54:39-48

Ramasundaram P, Vennila S, Ingle RK (2007) Bt cotton performance and constraints in Central India. Outlook Agric 36(3):175-180

Ramessar K, Peremarti A, Gomez Galera S, Naqvi S, Moralejo M, Muñoz M, Capell T, Christou P (2007) Biosafety and risk assessment framework for selectable marker genes in transgenic crop plants. A case of the science not supporting the politics. Transgen Res 16:261-280

Ramessar K, Capell T, Twyman RM, Quemada H, Christou P (2008a) Trace and traceability - a call for regulatory harmony. Nat Biotechnol 26:975-978

Ramessar K, Rademacher T, Sack M, Stadlmann J, Platis D, Stiegler G, Labrou N, Altmann F, Ma J, Stöger E, Capell T, Christou P (2008b) Cost-effective production of a vaginal protein microbicide to prevent HIV transmission. Proc Natl Acad Sci USA 105:3727-3732

Ramessar K, Sabalza M, Capell T, Christou P (2008c) Corn plants: an ideal production platform for effective and safe molecular pharming. Plant Sci 174:409-419 
Ramessar K, Capell T, Twyman RM, Quemada H, Christou P (2009) Calling the tunes on transgenic crops-the case for regulatory harmony. Mol Breed 23:99-112

Ramessar K, Capell T, Twyman RM, Christou P (2010) Going to ridiculous lengths-European coexistence regulations for GM crops. Nat Biotechnol 28:133-136

RF Service (2007) A growing threat down on the farm. Science 316:1114-1117

Ricroch A, Bergé JB, Kuntz M (2010) Is the German suspension of MON810 corn cultivation scientifically justified? Transgenic Res 19:1-12

Romeis J, Meissle M, Bigler F (2006) Transgenic crops expressing Bacillus thuringiensis toxins and biological control. Nat Biotechnol 24:63-71

Rosati A, Bogani P, Santarlasci A, Buiatti M (2008) Characterisation of 3'transgene insertion site and derived mRNAs in MON810 yield gard maize. Plant Mol Biol 67:271-281

Sabalza M, Miralpeix B, Twyman RM, Capell T, Christou P (2011) EU legitimizes GM crop exclusion zones. Nat Biotechnol 29:315-317

Sanahuja G, Subhasappa RB, Twyman RM, Capell T, Christou P (2011) Bacillus thuringiensis - a century of research, development and commercial applications. Plant Biotechnol J 9:283-300

Schimmelpfennig DE, Pray CE, Brennan MF (2004) The impact of seed industry concentration on innovation: a study of US biotech market leaders. Agric Econ 30:157-167

Sears MK, Hellmich RL, Stanley-Horn DE, Oberhauser KS, Pleasants JM, Mattila HR, Siegfried BD, Dively GP (2001) Impact of Bt corn pollen on monarch butterfly populations: a risk assessment. Proc Natl Acad Sci USA 98:11937-11942

Shelton AM, Sears MK (2001) The monarch butterfly controversy: scientific interpretations of a phenomenon. Plant J 27:483-488

Smale M, Zambrano P, Gruère G, Falck-Zepeda J, Matuschke I, Horna D, Nagarajan L, Yerramareddy I, Jones H (2009) Measuring the economic impacts of transgenic crops in developing agriculture during the first decade. IFPRI Food Policy Reviews, IFPRI, Washington DC

Snow A (2009) Unwanted transgenes re-discovered in oaxacan maize. Mol Ecol 18:569-571

Stoger E, Ma JK, Fischer R, Christou P (2005) Sowing the seeds of success: pharmaceutical proteins from plants. Curr Opin Biotechnol 16:167-173

Subramanian A, Qaim M (2010) The impact of Bt cotton on poor households in rural India. J Dev Stud 46:295-311

Sussman GL, Tarlo S, Dolovich J (1991) The spectrum of IgEmediated responses to latex. JAMA 265:2844-2847

Svitashev SK, Somers DA (2001) Genomic interspersions determine the size and complexity of transgene loci in transgenic plants produced by microprojectile bombardment. Genome 44:691-697
Tebrügge F (2010) No-tillage visions-protection of soil, water and climate and influence on management and farm income. In: García-Torres L, Benites J, Martínez-Vilela A, Holgado-Cabrera A (eds) Conservation agriculture: environment, farmers experiences, innovations, socio-economy, policy. Springer, NY, pp 327-340

The Guardian (2003) Brain drain threatens GM crop research. The Guardian, 23-09-2003

The Guardian (2004) Syngenta moves GM research to America. The Guardian, 02-07-2004

Torres et al (2007) Estimated fumonisin exposure in Guatemala is greatest in consumers of lowland corn. J Nutr 137:2723-2729

Twyman RM, Ramessar K, Quemada H, Capell T, Christou P (2009) Plant biotechnology: the importance of being accurate. Trends Biotechnol 27:609-612

USDA (2009) US Department of Agriculture GAIN Report: EU-27 Biotechnology. GE Plants and Animals. USDA, Washington, DC

Wang S (2008) Bt cotton and secondary pests. Int J Biotechnol 10(2-3):113-121

Weinthal D, Tovkach A, Zeevi V, Tzfira T (2010) Genome editing in plant cells by zinc finger nucleases. Trends Plant Sci 15:308-321

Williams et al (2010) HIV and hepatocellular and esophageal carcinomas related to consumption of mycotoxin-prone foods in sub-Saharan Africa. Am J Clin Nutr 92:154-160

Wu F (2006) Mycotoxin reduction in Bt corn: potential economic, health, and regulatory impacts. Transgen Res 15:277-289

Wu F, Miller JD, Casman EA (2004) The economic impact of Bt corn resulting from mycotoxin reduction. J Toxicol 23:397-424

Ye VM, Bhatia SK (2012) Metabolic engineering for the production of clinically important molecules: omega-3 fatty acids, artemisinin, and taxol. Biotechnol J 7:20-33

Yuan D, Bassie L, Sabalza M, Miralpeix B, Dashevskaya S, Farre G, Rivera SM, Subhasappa RB, Bai C, Sanahuja G, Arjo G, Avilla E, Zorrilla-Lopez U, Ugido N, Lopez A, Almacellas D, Zhu C, Capell T, Hahne G, Twyman RM, Christou P (2011) The potential impact of plant biotechnology on the millennium development goals. Plant Cell Rep 30:249-265

Zhu C, Naqvi S, Gomez-Galera S, Pelacho AM, Capell T, Christou P (2007) Transgenic strategies for the nutritional enhancement of plants. Trends Plant Sci 12:548-555

Zhu C, Naqvi S, Breitenbach J, Sandmann G, Christou P, Capell T (2008) Combinatorial genetic transformation generates a library of metabolic phenotypes for the carotenoid pathway in corn. Proc Natl Acad Sci USA 105:18232-18237

Zhu C, Sanahuja G, Yuan D, Farre G, Arjo G, Berman J, Zorrilla U, Raviral B, Bai C, Pérez-Massot E, Bassie L, Capell T, Christou P (2012) Biofortification of plants with altered antioxidant content and composition: genetic engineering strategies. Plant Biotechnol J. doi:10.1111/J.1467-7652.00740.x 